\title{
Makna Dan Pesan Bertato (Analisis Deskriptif Kualitatif Dalam Pandangan Pengguna Tato Di Studio Praboe Jazz Tattoo Yogyakarta)
}

\section{Meanings and Message of Tattooing (A Descriptive Qualitative Analysis in The View Tattoo Users in Studio Praboe Jazz Tattoo Yogyakarta)}

\author{
Mochammad Assad Fadlyan, Kristina Andryani \\ Universitas Mercu Buana Yogyakarta, Indonesia
}

\begin{abstract}
Abstrak
Tato merupakan suatu seni melukis tubuh yang menggunakan tubuh manusia sebagai tempat mengekspresikan diri. Studio Praboe Jazz Tattoo Yogyakarta adalah salah satu tempat pembuatan tato yang sudah beridiri sejak 1998. Tempat ini juga yang menjadi salah satu pendorong dari berkembangnya seni tato di Yogyakarta. Dari hal tersebut peneliti memilih empat informan pengguna tato yang berada di studio Praboe Jazz sebagai obyek pengumpulan data yang dikumpulkan melalui observasi dan wawancara secara mendalam. Dari hasil penelitian, ditemukan bahwa tato bisa menjadi sebuah tanda yang mewakili jati diri penggunanya, simbol-simbol yang terdapat pada tato yang digunakan pada dasarnya memiliki sebuah makna dan pesan bagi masing-masing penggunanya. Makna dan pesan tersebut biasanya terbentuk dari interaksi mereka dengan lingkungannya yang berkembang menjadi konsep diri. Setiap orang memiliki konsep diri yang berbeda-beda begitu juga dengan cara mereka menanggapi pandangan orang terhadap diri mereka.

Kata Kunci: Makna dan Pesan, Interaksi Simbolik, Konsep Diri, Praboe Jazz Tattoo Yogyakarta
\end{abstract}

\begin{abstract}
A tattoo is an art of body painting that used human body as a medium to expert himself or herself. Praboe Jazz Tattoo Studio is one of tattoo studios located in Yogyakarta concerned with art tattoos. This place has been around since 1998. This place can be considered as one of the promoters for art tattoos to be known and expanded in Yogyakarta. The researcher selects this place for conducting the data of the study. Four informants are obtained through in-depth observations and interviews. The result show that for most part of people, tattoos can represent the identity of their user. Also, symbols in tattoos for some extent can embody a certain message and meaning of each person who wear them. These message and meaning are generally formed from their interaction to surroundings that become a self concept. In this case, each person may have distinctive self concept.

Keywords: Meanings and Messages, symbolic interaction, self concept, Praboe Jazz
\end{abstract}




\section{PENDAHULUAN}

Komunikasi dan informasi sangat berperan penting bagi kehidupan manusia baik dulu hingga sekarang, namun pada zaman yang sudah modern seperti sekarang tato sudah tidak lagi digunakan untuk hal tersebut. Saat ini seni merajah atau tato menjadi suatu kebudayaan tersendiri bagi wilayah-wilayah tertentu seperti Filipina, Jepang, Kamboja, Tiongkok, Amerika dan juga Eropa. Tidak hanya di negara maju, Indonesia pun memiliki budaya atau seni tato tubuh yang diantaranya berasal dari suku Mentawai dari Sumatera, suku Dayak dari Kalimantam dan suku Moi dari Papua yang juga memiliki ciri khas dari masing-masing suku.

Kesenian mengacu pada nilai keindahan (estetika) yang berasal dari ekspresi hasrat manusia akan keindahan yang dinikmati dengan mata ataupun telinga. Sebagai makhluk yang mempunyai cita rasa tinggi. manusia menghasilkan berbagai corak kesenian, mulai dari yang sederhana hingga perwujudan kesenian yang kompleks. Dengan adanya perubahan yang terus berjalan seni melukis tubuhpun semakin berkembang dan saat ini tato sudah menjadi tren serta sangat populer di seluruh dunia.

Dengan kepopulerannya banyak orang yang menggunakan tato sebagai bagian dari fashion, di Indonesia sendiri para selebriti dan juga olahragawan menggunakan tato sebagai hiasan tubuh agar lebih terlihat menarik dan keren. Tidak heran bahwasannya tato saat ini sudah menjadi sebuah tren dan gaya hidup masyarakat di perkotaan, yang mana para pengguna tato biasanya sangat digemari oleh anak muda baik pria maupun wanita.

Makna Dan Pesan Bertato (Analisis Deskriptif Kualitatif Dalam Pandangan Pengguna Tato Di Studio Praboe Jazz Tattoo 
Seiring dengan berjalannya waktu dalam masyarakat modern, tato sudah mengalami perubahan makna yang tadinya tato hanya digunakan sebagai suatu penanda dan seni. Secara garis besar ada pihak yang mendukung budaya dan seni tersebut serta ada juga yang tidak mendukung keberadaannya. Pandangan buruk terhadap tato ini juga diperkuat oleh media masa, opini yang dipengaruhi oleh pemerintah baik media cetak maupun eletronik membuat masyarakat semakin mejauhi seni tato ini.

Terlepas dari semua kontroversi tersebut, proses pembuatan tato saat ini juga sudah sangat berkembang, dari yang awalnya tato hanya dibuat dengan menggunakan alat yang sangat sederhana seperti orang zaman dahulu yang membuat tato dari tulang dan jarum, kemudian terus mengalami kemajuan dengan menggunakan jarum dari besi yang dimodifikasi dengan mesin dinamo untuk mempermudah proses mengukir desain tato pada kulit di tubuh manusia.

Berkembangnya seni budaya tato di Indonesia membuat studiostudio tatopun bermunculan dan terus bekermbang hingga saat ini. Yogyakarta merupakan salah satu kota yang memiliki budaya yang sangat lekat, tidak heran jika seni tatopun juga berkembang di kota ini. Fenomena tato masuk ke Yogykarta sudah ada sejak dulu sampai sekarang hingga berdirinya studio pembuatan tato di Yogyakarta.

Semakin banyak studio tatto yang berdiri di Yogyakarta salah satunya studio yang sudah berdiri cukup lama adalah Studio Praboe Jazz tatoo yang telah berdiri sejak 1998 yang mana sudah berkontribusi untuk perkembangan tato di Yogyakarta kurang lebih sekitar 21 tahun. Peneletian ini didasari oleh keingintahuan peneliti 
terkait makna dan pesan bertato dalam berbagai macam pendapat dan pandangan. Bagaimana komunikasi yang terjalin antara para pengguna tato dengan lingkungan masyarakat, seperti yang kita ketahui seni ini merupakan seni yang kontroversial, banyak pandangan negatif di masyarakat tentang pengguna tato yang membuat sulitnya para pengguna tato untuk menunjukan hobi mereka dalam bertato kepada lingkungannya.

\section{METODE PENELITIAN}

\section{Jenis Penelitian}

Dilihat dari sifatnya penelitian ini termasuk penelitian deskriptif kualitatif yang mana menekankan realitas atau kenyataan yang terjadi di masyarakat, melalui wawancara dan observasi serta data yang akurat dan tidak dibuat-buat. Dimana menjelaskan fenomena yang ada dengan sistematis sesuai dengan fakta yangada. Dilihat dari sifatnya penelitian ini termasuk penelitian deskriptif kualitatif yang mana menekankan realitas atau kenyataan yang terjadi di masyarakat, melalui wawancara dan observasi serta data yang akurat dan tidak dibuat-buat. Dimana menjelaskan fenomena yang ada dengan sistematis sesuai dengan fakta yang ada.

\section{Fokus Penelitian}

Fokus dari penelitian yang diambil oleh peneliti dalam penelitian ini menggunakan 3 cara antara lain yaitu (Observasi, Wawancara, dan Dokumentasi).

\section{Lokasi Penelitian}

Dalam pengambilan data di lapangan, penelitian ini akan dilakukan

Makna Dan Pesan Bertato (Analisis Deskriptif Kualitatif Dalam Pandangan Pengguna Tato Di Studio Praboe Jazz Tattoo Yogyakarta)

Meanings and Message of Tattooing (A Descriptive Qualitative Analysis in The View Tattoo Users in Studio Praboe Jazz Tattoo Yogyakarta) Mochammad Assad Fadlyan, Kristina Andryani 
di Studio Praboe Jazz Tattoo yang beralamat di jalan Affandi No.17, Karang Gayam, Caturtunggal, Kec. Depok, Kabupaten Sleman, Daerah Istimewa Yogyakarta.

\section{Subyek dan Obyek Penelitian}

1. Subyek yang terdapat dalam penelitian ini antara lain adalah seniman tato dan pengguna tato di Studio Praboe Jazz di Yogyakarta. Untuk subyek pertama adalah seniman tattoo yang bernama Deddy dia adalah seniman tato sekaligus pengguna tato dan pemilik dari Studio Praboe Jazz. Kemudian untuk subyek berikutnya adalah para pengguna tattoo yang terdiri dari beberapa orang pengguna tato di Studio Praboe Jazz yang nantinya akan disesuaikan dengan kebutuhan informasi peneliti.

2. Sumber penelitian ini akan berfokus di Studio Praboe Jazz Wilayah Kabupaten Sleman Yogyakarta yang mana di studio tersebut ada kegiatan pembuatan tattoo yang sedang eksis dan menjadi faktor dari pembuatan penelitian ini.

\section{Metode Pengumpulan Data}

1. Observasi adalah tahapan pertama yang dilakukan peneliti, dalam observasi tersebut peneliti mengamati secara langsung terkait kegiatan yang dilakukan oleh seniman tato, walaupun hanya mengamati dan mendengarkan subyek tanpa ikut langsung kegiatan yang mereka lakukan. Penulis akan mencoba mengidentifikasi, mengamati, dan memperhatikan interaksisosial yang terjadi antara seniman tato, penggemar tato maupun masyarakat yang menanggapi fenomena penggunaan tato tersebut. 
2. Wawancara adalah tahapan kedua yang dilakukan peneliti, wawancara sendiri merupakan teknik pengumpulan data dengan proses tanya jawab antara peneliti dan partisipan untuk meraih data lebih dalam terkait penelitian yang dilakukan. Teknik ini dilaksanakan dengan melakukan wawancara secara langsung dengan narasumber yang diantaranya adalah artist tato yang bernama (inisial) D berusia 38 tahun, tukang tato yang bernama K berusia 24 tahun, pengguna tato yang bernama E berusia 28 tahun dan D yang berumur 32 tahun.

\section{HASIL DAN PEMBAHASAN}

\section{Pemaknaan sebuah pesan tattoo}

Para pengguna tato di Studio Praboe Jazz dalam proses mengekspresikan diri, mereka menggunakan tato yang mempunyai berbagai macam jenis, bentuk dan aliran. Hal ini dapat membuat mereka lebih bebas dalam mengungkapkan pemikiran mereka masing-masing.

Jika sebuah tato bisa digunakan dengan baik dan semestinya sebuah seni, tato akan menjadi sebuah alat yang sangat berguna, karena tato bisa menjadi faktor pendorong motivasi untuk hidup seseorang dari kenangan hingga mengabadikan suatu momen di dalam sebuah tato. Oleh karena itu disetiap pembuatan tato akan ada maksud dan pesan didalamnya, jika pesan tersebut ditafsirtkan pesan tersebut akan mengandung suatu makna, yang mana makna tersebut muncul dari pengalaman orang masing-masing dan mempunyai arti yang berbeda-beda sesuai dengan pengalaman hidup dan pribadi

Makna Dan Pesan Bertato (Analisis Deskriptif Kualitatif Dalam Pandangan Pengguna Tato Di Studio Praboe Jazz Tattoo 
orang tersebut.

\section{Simbolisasi Terhadap Diri Pengguna Tato}

Sebuah tato adalah perlambangan dari simbol yang menggambarkan diri seseorang, simbol tersebut memberikan sebuah kesan kepada orang yang menggunakannya, kesan tersebut muncul dari interaksi yang terjadi antara individu maupun sekelompok orang.

Walaupun sebuah simbol tato memiliki perbedaan arti dan makna dari padangan setiap orang, namun dalam proses pembentukan suatu tato yang disimbolkan oleh setiap individu akan terbentuk dari proses yang dinamakan interaksi simbolik. Interakasi simbolik merupakan teori yang menjelaskan tentang pembentukan suatu makna antara satu individu dengan individu lain yang melalui proses komunikasi, jadi setiap orang mempunyai caranya masing-masing dalam berkomunikasi dapat juga terjadi dengan menggunakan simbol yang ada pada tato, karena dalam kehidupan sehari-haripun manusia menggunakan simbolsimbol untuk menyampaikan suatu pesan.

Tato akan mempunyai makna dan simbol juga bagi orang lain yang melihatnya, baik itu simbol secara positif maupun negatif, terlepas dari itu juga kita tidak bisa sembarangan dalam memilih bentuk tato, karena tato adalah sebuah budaya jadi ada simbol-simbol dan makna tertentu untuk masyarakat tradisional, diharapakan jika kita kurang mengerti akan lambang tato budaya lebih baik memakai tato modern saja.

Banyak faktor yang menyebabkan tato tidak disukai oleh sebagian besar masyarakat, salah satunya adalah menyimbolkan tato sebagai sesuatu yang buruk khususnya di wilayah Yogyakarta. Menurut seniman dan pengguna tato di studio prabo jazz sendiri, mereka sama sekali tidak menyalahkan tentang 
tanggapan buruk terhadap orang-orang yang menggunakan tato.

Mereka lebih menyalahkan sistem budaya di masyarakat yang sudah terbentuk dari zaman dahulu, yang mana setiap orang yang berbeda selalu dipaksa untuk menyamaratakan setiap pandangan dan perilaku mereka. Jika dilihat dari teori interaksi simbolik sebenarnya proses pemaknaan terhadap tato berasal dari tiga konsep, yang mana konsep terebut dipengaruhi oleh diri sendiri dan lingkungannya yang diantaranya adalah sebagai berikut:

1. Pikiran (Mind) merupakan proses awal berfikir sebelum individu melakukan sesuatu, hal ini juga berlaku pada simbolisasi terhadap pengguna tato, setiap pengguna tato berinteraksi dan melihat respon orang-orang terhadap diri mereka. Dari respon tersebut merekapun bisa menilai diri mereka bagaimana pandangan orang terhadap mereka. Karena pada dasarnya seseorang untuk menyimbolkan dan menilai sesuatu tidak langsung muncul begitu saja, namun mempunyai sebuah proses yang mana proses tersebut diawali dengan pemikiran terlebih dahulu.

2. Diri (Self). Dalam hal ini diri merupakan pandangan tentang diri kita bagaimana kita memandang dan menilai diri kita sendiri, namun proses menilai tersebut kita lihat dari sudut pandang orang lain. Jadi sebelum seseorang melakukan sesuatu dia harus mempertimbangkan pendapat ataupun penilaian orang terlebih dahulu, walaupun hal tersebut bertentangan dengan konsep diri mereka. Dari sudut pandang pengguna tato mereka merasa diri mereka sendiri terkekang karena berbuat sesuatu berdasarkan pandangan orang lain, mereka ingin mengekspresikan diri mereka dan melakukan sesuatu yang berbeda bukan melakukan sesuatu berdasarkan mayoritas orang yang melakukannya.

3. Masyarakat (Society) merupakan pembentukan perilaku dari setiap individu

Makna Dan Pesan Bertato (Analisis Deskriptif Kualitatif Dalam Pandangan Pengguna Tato Di Studio Praboe Jazz Tattoo 
yang mana perilaku tersebut dibatasi oleh norma-norma yang ada di masyarakat. Walaupun dalam keputusannya tetap kembali lagi terhadap individu masing-masing yang tentunya dari perbuatan tersebut ada dampak yang diterima juga. Dari penjelasan sebelumnya pengguna tato sendiri tidak menyalahkan pandangan buruk dan dampak sosial yang diterima mereka, namun mereka lebih menyalahkan sistem budaya yang ada di masyarakat.

\section{Pembentukan Konsep Diri Pengguna Tato}

Konsep diri merupakan pemikiran tentang diri individu sendiri yang muncul dari pengalaman serta interaksi sosial di kehidupan sehari-hari. Setiap pengguna tato pasti memiliki alasan sendiri kenapa mereka menggunakan tato di tubuh mereka, yang mana alasan tersebut membentuk sebuah konsep diri, seperti yang sudah diketahui bahwa setiap konsep diri individu berbeda-beda tergantung dari pengalaman hidup individu masing-masing. Jika dilihat dalam pandangan konsep diri, para pengguna tato memiliki beberapa faktor yang mempengaruhi keputusan mereka untuk membuat tato atau tidak, baik itu faktor dari lingkungan keluarga yang melarang mereka untuk menggunakan tato dan mengarapkan perilaku tertentu terhadap diri mereka, maupun lingkungan sosial pengguna tato sendiri.

Lingkungan tersebut baik di lingkungan tempat kerja, bermain, sekolah, yang mana mempengaruhi setiap keputusan mereka yang akhirnya berfikir dan memutuskan untuk menggunakan tato di tubuh. Dari hal tersebut dapat kita kaitkan dengan teori konsep diri yang mana konsep diri dipengaruhi oleh beberapa faktor dan aspek yang diantaranya adalah sebagai berikut: 
1. Orang lain (Significant Other) merupakan orang-orang yang mempunyai peran penting dan dianggap istimewa dalam hidup seseorang. Orang tersebut bisa termasuk orang tua, keluarga, pasangan dan juga sahabat, pandangan orang tersebut sangat berpengaruh terhadap perilaku individu. Orang lain (Significant Other) sangatlah mempengaruhi perilaku dan keputusan seseorang untuk melakukan sesuatu ataupun berhenti melakukannya, bagi pengguna tato sendiri banyak pertimbangan yang harus mereka lihat untuk mengekspresikan diri mereka dengan tato.

2. Kelompok Rujukan (Reference Group). Setiap individu sebagai makhluk sosial pasti berinteraksi dan berkomunikasi terhadap suatu kelompok di lingkungan sosialnya, dalam kelompok tersebut memiliki aturannya masing-masing dimana individu biasanya ketika sudah masuk ke kelompok tersebut secara tidak langsung akan mengikuti aturan, perilaku serta pandangan dari kelompok tersebut.

3. Pandangan terhadap diri pengguna tato Setiap orang mempunyai konsep diri dan pandangan terhadap dirinya masing-masing, pandangan tersebut bisa bersifat negatif maupun positif tergantung dari individu menanggapi diri pribadinya. Hal tersebut berkaitan dengan bagaimana setiap individu mengatasi permasalahan dalam diri mereka, karena tidak setiap orang bisa menerima keadaan diri mereka yang sekarang. 


\section{KESIMPULAN}

Setiap pengguna tato memiliki makna dan pesan yang bebeda-beda untuk tato yang mereka buat, namun dari setiap tato tersebut mempunyai kesamaan arti dan tanda yang mana bentuk dari tato yang mereka buat menyimbolkan pengalaman hidup dari diri pengguna tato tersebut.

Namun terlepas dari hal tersebut tujuan awal mereka menggunakan tato karena menyukai dan mencintai seni tato. Tato merupakan seni melukis tubuh yang menggunakan tubuh manusia sebagai tempat mengekspresikan diri, di masyarakat modern saat ini seni tato sudah menjadi sebuah trend, fashion dan gaya hidup yang sangat populer.

Banyak orang-orang yang mulai tertarik pada seni tato khususnya di daerah perkotaan, di Yogyakarta sendiri sudah sangat banyak orang-orang yang tertarik dan berkeinginan untuk menggunakan tato. Studio Praboe Jazz tattoo Yogyakarta adalah salah satu tempat pembuatan tato yang sudah beridiri sejak 1998 di Yogyakarta, tempat ini juga yang menjadi salah satu pendorong dari berkembangnya seni tato di Yogyakarta. Dari hal tersebut peneliti memilih empat informan pengguna tato yang berada di studio Praboe Jazz sebagai obyek pengumpulan data yang dikumpulkan melalui observasi dan wawancara secara mendalam.

Dari hasil penilitian ini ditemukan bahwa pada sebagian besar orang, tato bisa menjadi sebuah tanda yang mewakili jati diri penggunanya, simbolsimbol yang terdapat pada tato yang digunakan pada dasarnya memiliki sebuah makna dan pesan bagi masing-masing penggunanya. Makna dan pesan tersebut biasanya terbentuk dari interaksi mereka dengan lingkungannya yang berkembang menjadi konsep diri, setiap orang memiliki konsep diri yang berbeda-beda begitu juga dengan cara mereka menanggapi 
pandangan orang terhadap diri mereka baik itu secara positif maupun negatif.

\section{DAFTAR REFERENSI}

Ardianto, E., Komala L., and Karlinah S. (2007). Komunikasi Massa Suatu Pengantar Revisi. Bandung: Simbiosa Rekatama Media.

Berger A.A. (2004). Tanda-Tanda Dalam Kebudayaan Kotemporer, trans. M. Dwi Mariyanto dan Sunarto. Tiara Wacana.

Bachtiar, W. (2006). Sosiologi Klasik Dari Comte hingga Parsons. Bandung: Remaja Rosdakarya.

Berzonsky. (1981). Adolescence Development. New York: Mcmillan Publishing.Co Inc.

Danesi, M. (2012). Pesan, Tanda dan Makna, Buku Teks Dasar Semiotika dan Teori komunikasi. Yogyakarta: Jalasutra.

Desmita. (2012). Psikologi Perkembangan. Bandung: Remaja Rosdakarya.

Fiske, J. (2012). Pengantar Ilmu Komunikasi. Jakarta: Rajawali Pers.

Guffron, M., Nur, R.R. (2010). Teori-teori Psikologi. Yogyakarta: Ar-ruzz media.

Haryanto. (2012). Spektrum Teori Sosial Dari Klasik Hingga Postmodern. Yogyakarta: Ar Ruszz Media.

Wirawan, I.B. (2014). Teori-Teori Sosial Dalam Tiga Paradigma, Fakta Sosial, Definisi Sosial, dan Perilaku Sosial. Jakarta: Kencana.

Ikbar, Y. (2012). Metode Penelitian Sosial Kualitatif. Bandung: PT Refika Aditama.

Moleong, L.J. (2008). Metodologi Penelitian Kualitatif. Bandung: PT Remaja Rosda Karya.

Mulyana, D. (2001). Ilmu Komunikasi, suatu pengantar. Bandung: Remaja Rosdakarya.

Mulyana, D. (2005). Ilmu Komunikasi, Suatu pengantar. Jakarta: Rosdakarya.

Rahmat, J. (2007). Psikologi Komunikasi. Bandung: Remaja Roskdakarya.

Rakhmat, J. (2003). Psikologi Komunikasi Edisi Revisi. Bandung: PT Remaja Rosdakarya.

Sobur, A. (2004). Semiotika Komunikasi. Bandung: PT Remaja Rosdakarya. Sunyoto, D. (2015). Perilaku Konsumen dan Pemasaran-Panduan Riset Sederhana untuk Mengenali Konsumen. Jakarta: PT Buku Seru.

Makna Dan Pesan Bertato (Analisis Deskriptif Kualitatif Dalam Pandangan Pengguna Tato Di Studio Praboe Jazz Tattoo

Meanings and Message of Tattooing (A Descriptive Qualitative Analysis in The View Tattoo Users in Studio Praboe Jazz Tattoo Yogyakarta) 
Fuad Nuzul Kurniawan. Persepsi Wanita Jawa Yang Menghias Tubuh Dengan Tato Terhadap Penerimaan Sosial. (Skripsi, Fakultas Psikologi UMB, Yogyakarta, 2018).

Georgius Priyanto. Motivasi Remaja Bertato (Studi Kasus Tentang Motivasi Bertato Pada Dua Remaja di Yogyakarta). (Skripsi, Fakultas Keguruan dan Ilmu Pendidikan USD, Yogyakarta, 2019).

Yoga Pebriana Slamba. Perubahan Makna Tato Di Kalangan Remaja Muslim (Studi Kasus Di Desa Martapada Wetan Kabupaten Cirebon). (Skripsi, Fakultas Ushuludin dan Pemikiran Islam UIN Sunan Kalijaga, Yogyakarta, 2017). 